\title{
Z prawnej problematyki organizacji producentów rolnych - wybrane zagadnienia
}

\author{
Legal issues of agricultural producer organisations - selected problems
}

\section{Wprowadzenie}

W świetle regulacji unijnych (Wspólnej Polityki Rolnej) organizacje producentów rolnych mają przyczyniać się do wzmocnienia pozycji rolników w łańcuchu dostaw żywności, rozwoju gospodarstw rolnych i rynków rolnych (Komisja Europejska, 2019). Punkt 131 preambuły rozporządzenia Parlamentu Europejskiego i Rady (UE) nr 1308/2013 z 17 grudnia 2013 r. ustanawiającego wspólną organizację rynków produktów rolnych oraz uchylające rozporządzenia Rady (EWG) nr 922/72, (EWG) nr 234/79, (WE) nr 1037/2001 i (WE) nr 1234/2007 (Dz. Urz. EU L z 2013 r., Nr 347/671 ze zm.; dalej: rozporządzenie Parlamentu Europejskiego i Rady (UE) nr 1308/2013 z 17 grudnia 2013 r.) wskazuje, że:

Organizacje producentów i ich zrzeszenia mogą pełnić użyteczną rolę w koncentracji podaży, poprawie wprowadzania do obrotu, planowania i dostosowywania produkcji do popytu, w optymalizacji kosztów produkcji i stabilizowaniu cen producenta, prowadzeniu badań, promowaniu najlepszych praktyk i oferowaniu pomocy technicznej, gospodarowaniu produktami ubocznymi i zarządzaniu narzędziami zarządzania ryzykiem dostępnymi dla ich członków.

W niektórych krajach widoczny jest rozwój tego rodzaju podmiotów. Przykładowo na początku 2020 r. we Francji we wszystkich sektorach łącznie funkcjonowały 633 organizacje producentów i 25 stowarzyszeń uznanych organi- 
zacji producentów(Del Cont, 2020; Ministère de l'Agriculture et de l’Alimentation, 2020). W Niemczech już w 2012 r. istniały 904 organizacje producentów rolnych (Busse, 2013, 2020). Natomiast w całej Unii Europejskiej w połowie 2017 r. działalność prowadziło 3434 organizacji producentów rolnych i 71 zrzeszeń, z tego 50\% miało formę spółdzielni (Komisja Europejska, 2019).

W Polsce uznano tylko organizacje producentów owoców i warzyw mające już pewną tradycję, ale w tym zakresie obowiązują odrębne regulacje prawne (Suchoń, 2013, s. 11-32). Natomiast, jak dotąd nie została zarejestrowana żadna organizacja producentów rolnych na innym rynku, w tym mleka. Ustawodawca krajowy stara się zachęcić do zrzeszania się rolników i składania wniosków o uznawanie organizacji. Z tego powodu w ostatnich latach zmieniono i wydano nowe regulacje prawne. Przykładowo 20 maja 2020 r. weszło w życie rozporządzenie Ministra Rolnictwa i Rozwoju Wsi z 27 kwietnia 2020 r. zmieniające rozporządzenie w sprawie szczegółowych warunków i trybu przyznawania, wypłaty oraz zwrotu pomocy finansowej w ramach działania „Tworzenie grup producentów i organizacji producentów” objętego Programem Rozwoju Obszarów Wiejskich na lata 2014-2020 (Dz.U. 2020, poz. 799). Dzięki tej nowelizacji z unijnych środków finansowych mogą skorzystać nie tylko grupy producentów rolnych, lecz także organizacje. W latach 2019-2020 znowelizowane zostały również rozporządzenia wykonawcze do ustawy z 20 kwietnia 2004 r. o organizacji rynku mleka i przetworów mlecznych (Dz.U. 2019, poz. 1430 ze zm.) oraz ustawy z 11 marca 2004 r. o organizacji niektórych rynków rolnych (Dz.U. 2018, poz. 945; 2019, poz. 2020) dotyczące wybranych kwestii zakładania organizacji producentów rolnych, w tym mleka.

Podjęcie badań dotyczących organizacji producentów rolnych uzasadniają różne motywy, m.in. poznawcze, praktyczne i gospodarcze. Jak dotąd zagadnienie to było rzadko poruszane w polskiej literaturze (Busse, 2013, s. 173-188; Suchoń, 2015, s. 133-150, 2016, 2020). Jest natomiast popularne w zagranicznych opracowaniach (np. Zoeteweij-Turhan, 2012; Ton, Bijman, Oorthuizen (eds.), 2007; Petriccione, Solazzo, 2012; Canfora, 2018; Le Clerc, Bouamra-Mechemache, Duvaleix-Treguer, Magdelaine, Roguet et G. You, 2019; FAO, 2010; Van Herck, 2014; Komisja Europejska, 2019; Mwambi, Bijman, Mshenga, 2020; Rondot, Collion (eds.), 2001). Brakuje zatem w tym zakresie prac krajowych.

Poza tym obecnie aktualnym dla Unii Europejskiej tematem jest realizacja strategii Komisji Europejskiej „od pola do stołu” na rzecz sprawiedliwego, zdrowego i przyjaznego dla środowiska systemu żywnościowego (F2F) z 20 maja 2020 r. (Komisja Europejska, 2020). Celem tego dokumentu jest całościowa zmiana podejścia do produkcji żywności. (Komisja Europejska, 2020). 
Do realizacji wskazanych celów może przyczynić się działalność organizacji producentów rolnych. Ich współpraca jest potrzebna na różnych etapach prowadzenia działalności rolniczej - począwszy od zakupu środków produkcji, poprzez korzystanie z maszyn rolniczych, sprzedaż i transport plonów, doradztwo, aż po przetwórstwo (Komisja Europejska, 2020).

W artykule podjęto próbę określenia kształtu prawnego zakładania, uznawania i funkcjonowania organizacji producentów rolnych (ze szczególnym uwzględnieniem zmian regulacji prawnych z 2019 i 2020) oraz ich oceny w kontekście obecnych wyzwań dotyczących gospodarstw rolnych, rynków rolnych oraz polityk unijnych. Starano się także ustalić, które regulacje prawne stanowią barierę w zakresie zakładania i rozwoju organizacji producentów rolnych oraz wskazać propozycji ich zmiany.

Problematyka organizacji producentów rolnych jest wieloaspektowa, a ramy artykułu ograniczone. Dlatego w pierwszej kolejności rozważania będą koncentrowały się na przepisach unijnych, a następnie polskich. Struktura taka pozwoli na dokonanie ich oceny i zaproponowanie ewentualnych modyfikacji krajowych regulacji prawnych.

\section{Organizacje na innych rynkach niż rynek mleka}

\subsection{Regulacje unijne}

Podstawowe unijne regulacje prawne dotyczące organizacji producentów rolnych zawarto w rozporządzeniu Parlamentu Europejskiego i Rady (UE) nr 1308/2013 z 17 grudnia 2013 r. ustanawiającym wspólną organizację rynków produktów rolnych oraz uchylającym rozporządzenia Rady (EWG) nr 922/72, (EWG) nr 234/79, (WE) nr 1037/2001 i (WE) nr 1234/2007 (Dz. Urz. EU L z 2017 r., $\mathrm{Nr} 347 / 671$ ze zm.) oraz w rozporządzeniu Parlamentu Europejskiego i Rady (UE) nr 1305/2013 z 17 grudnia 2013 r. w sprawie wsparcia rozwoju obszarów wiejskich przez Europejski Fundusz Rolny na rzecz Rozwoju Obszarów Wiejskich (EFRROW) i uchylającym rozporządzenie Rady (WE) nr 1698/2005 (Dz. Urz. UE L z 2013 r., Nr 347, s. 487 ze zm.).

Artykuł 152 rozporządzenia Parlamentu Europejskiego i Rady (UE) nr 1308/2013 z 17 grudnia 2013 r. określa ogólnie, że państwa członkowskie mogą na wniosek uznawać organizacje producentów (zmieniony rozporządzeniem z 13 grudnia 2017 r.; Dz. Urz. UE. L z 2017 r. Nr 350, poz. 15, które stosuje się 
od 1 stycznia 2018 r.) i zarazem wymienia podstawowe zasady ich zakładania i prowadzenia działalności.

Przede wszystkim organizacje te są tworzone i kontrolowane przez producentów rolnych z określonego sektora wymienionego w art. 1 ust. 2 omawianego rozporządzenia, np. zboża, ryż, chmiel, wino, wieprzowina, baranina, cukier, owoce i warzywa, wołowina i cielęcina, mleko i przetwory mleczne, oliwki. Tak szerokie wskazanie pozwala na funkcjonowanie organizacji na wręcz wszystkich unijnych rynkach rolnych. Warto w tym miejscu zwrócić uwagę, że rozporządzenie nr 1234/2007 z 22 października 2007 r. ustanawiające wspólną organizację rynków rolnych oraz przepisy szczegółowe dotyczące niektórych produktów rolnych określało, że państwa członkowskie uznają organizacje producentów, które skupiają producentów jednego z następujących sektorów: (a) sektor chmielu; (b) sektor oliwek stołowych i oliwy z oliwek; (c) sektor jedwabników.

Szeroko określony został także zakres działalności organizacji w omawianym rozporządzeniu nr 1308/2013. Mogą one mianowicie prowadzić jedną lub większą liczbę aktywności wymienionych w art. 152 tego aktu prawnego. Dla rozwoju rynków rolnych i gospodarstw rolników istotne są szczególnie: wspólne przetwarzanie produktów rolnych (co pozwala na osiągnięcie wyższych dochodów); dystrybucja, w tym również wspólne platformy sprzedaży lub transport; wspólne pakowanie, etykietowanie lub promocja czy organizacja kontroli jakości. Na zmniejszenie kosztów prowadzenia działalności rolniczej wpływa pozytywnie zorganizowane wykorzystywanie urządzeń lub miejsc składowania; zarządzanie odpadami pochodzącymi bezpośrednio z produkcji; pozyskiwanie środków produkcji czy inne rodzaje wspólnej działalności usługowej.

Według rozporządzenia unijnego nr 1308/2013 owe organizacje producentów rolnych dążą do co najmniej jednego celu wskazanego w art. 152 rozporządzenia nr 1308/2013. Jest ich ponad dziesięć i można je podzielić na kilka grup. Łączą się one z działalnością wskazaną w punkcie poprzednim. Po pierwsze, te

związane z gospodarstwem rolnym i sprzedażą produktów rolnych. Przykładem może być zapewnienie planowania i dostosowywania produkcji do popytu, w szczególności w odniesieniu do jakości i ilości; koncentracja dostaw i umieszczanie na rynku produktów wytwarzanych przez ich członków, w tym sprzedaż bezpośrednia; optymalizacja kosztów produkcji innowacyjnych praktyk; poprawa jakości produktów i rozwijanie produktów o chronionej nazwie pochodzenia, chronionym oznaczeniu geograficznym lub objętych krajowym znakiem jakości). 
Po drugie, odnoszące się do ochrony środowiska (np. inwestycje służące utrzymywaniu standardów dotyczących ochrony środowiska i dobrostanu zwierząt;

prowadzenie badań i opracowywanie inicjatyw dotyczących zrównoważonych metod produkcji, innowacyjnych praktyk, konkurencyjności gospodarczej i rozwoju sytuacji rynkowej; zarządzanie produktami ubocznymi i odpadami, zwłaszcza w celu ochrony jakości wody, gleby i krajobrazu oraz zachowania lub zachęcania do utrzymania bioróżnorodności; przyczynianie się do zrównoważonego wykorzystania zasobów naturalnych oraz do łagodzenia zmiany klimatu).

Grupa trzecia: związane z inwestowaniem, pomocą techniczną,

opracowywaniem inicjatyw $\mathrm{w}$ dziedzinie promocji i wprowadzania do obrotu (np. zarządzanie funduszami wspólnego inwestowania, o których mowa w części poświęconej programom operacyjnym w sektorze owoców i warzyw; udzielanie niezbędnej pomocy technicznej w celu korzystania z rynków terminowych i systemów ubezpieczeń).

Szeroka działalność organizacji określona w przepisach unijnych zdaniem prawodawcy ma wpłynąć na ewolucję rozwoju zrzeszania się producentów rolnych - od lokalnych spółdzielni rolników czy grup producentów rolnych do większych i silniejszych organizacji producentów rolnych, które mają wyraźniej dążyć do wzmocnienia pozycji producenta rolnego w Europie i świecie. Artykuł L. 551-1 i nn. oraz art. D. 551-1 francuskiego Kodeksu rolnego zachęcają do uznawania zrzeszeń producentów rolnych za organizacje. Regulacje prawne w większości krajów mają zapewnić demokratyczny ustrój organizacji producentów rolnych i rozwój ekonomiczny gospodarstw rolnych oraz wpływ na rynek rolny regionalny, a także globalny (Bijman, 2016).

Nie ulega wątpliwości, że cele działania organizacji producentów rolnych zostały kompleksowo zdefiniowane. Część z nich wpisuje się w europejski Zielony Ład i opublikowane w maju 2020 r. przez Komisję Europejską dokumenty czyli unijne strategie na rzecz bioróżnorodności $2030 \mathrm{w}$ celu ochrony wrażliwych zasobów naturalnych na naszej planecie oraz strategii „od pola do stołu” (która zakłada stworzenie bardziej zrównoważonych systemów żywnościowych). Strategia ta uwzględnia obecne uwarunkowania konieczne dla rozwoju rynków rolnych i gospodarstw rolnych ( np. kwestie środowiskowe i żywnościowe). 
Należy ponownie wyraźnie podkreślić, że aktualnym dla Unii Europejskiej tematem jest realizacja strategii z 20 maja 2020 r. Komisji Europejskiej „od pola do stołu" na rzecz sprawiedliwego, zdrowego i przyjaznego dla środowiska systemu żywnościowego (F2F) (Komisja Europejska, 2020). Jej celem jest całościowa zmiana podejścia do produkcji żywności. Jest on niezmierne istotny w aspekcie obecnych wyzwań rozwoju gospodarstw rolnych i rynków rolnych. Wskazano w nim, że

łańcuch żywnościowy, obejmujący produkcję, transport, dystrybucję, marketing i konsumpcję żywności, powinien mieć neutralny lub pozytywny wpływ na środowisko, zwrócono też uwagę na zapewnienie bezpieczeństwa żywnościowego, żywienia i zdrowia publicznego, a także zachowanie przystępności cenowej żywności.

W strategii podkreślono, że pandemia COVID-19, coraz częstsze występowanie suszy, powodzi, pożarów lasów i nowych agrofagów przypomina o tym, że system żywnościowy jest zagrożony i musi stać się bardziej zrównoważony i odporny (Komisja Europejska, 2020).

Zrzeszeni producenci mogą wytwarzać produkty rolne z ograniczeniem stosowania pestycydów, prowadzić hodowlę czy chów z wykorzystaniem mniejszej ilości leków weterynaryjnych oraz zajmować się przetwórstwem, którego efektem będą produkty rolno-spożywcze niezafałszowane, zdrowe i tańsze dla konsumentów, mogą też angażować się w odnawialne źródła energii. Strategia "od pola do stołu” jest kluczowym elementem Zielonego Ładu UE, który obejmuje zrównoważoną i sprzyjającą włączeniu społecznemu strategię na rzecz wzrostu w celu pobudzenia gospodarki, poprawy zdrowia i jakości życia ludzi oraz dbania o przyrodę (Komisja Europejska, 2020).

Jednocześnie ustawodawca unijny zdając sobie sprawę, że funkcjonowanie organizacji producentów nie jest łatwe, chociażby z uwagi na wpływ warunków atmosferycznych na efekty działalności rolniczej (produkty rolne) jej członków, sezonowość i ograniczoną ilość gruntów rolnych, wprowadza pewne odstępstwa od zasad ogólnych Traktatu o Fukcjonowaniu Unii Europejskiej (dalej: TFUE). Artykuł 152 ust. la rozporządzenia unijnego dodany na podstawie nowelizacji (Dz. Urz. UE. L z 2017 r. Nr 350, poz. 15) i mający zastosowanie od 1 stycznia 2018 r. określa, że na zasadzie odstępstwa od art. 101 ust. 1 TFUE organizacja producentów może planować produkcję produktów rolnych, optymalizować koszty ich produkcji, wprowadzać je do obrotu oraz negocjować umowy dotyczące ich dostaw w imieniu swoich członków w odniesieniu do 
całości lub części ich łącznej produkcji. Trybunał Sprawiedliwości w wyroku z 14 listopada 2017 r. (C-671/15, Legalis nr 2255353) stwierdził m.in., że:

[...] praktyki polegające na zbiorowym ustalaniu minimalnych cen sprzedaży, uzgadnianiu ilości wprowadzanych na rynek lub wymianie informacji strategicznych, takie jak praktyki rozpatrywane w postępowaniu głównym, nie mogą zostać wyłączone z przewidzianego w art. 101 ust. 1 TFUE zakazu karteli, w sytuacji gdy uczestniczą w nich różne organizacje producentów lub zrzeszenia organizacji producentów. Zdaniem Trybunału powyższe mogą zostać wyłączone z zakresu przewidzianego w art. 101 ust. 1 TFUE, w sytuacji gdy uczestniczą w nich członkowie tej samej uznanej przez państwo członkowskie organizacji producentów.

Działalność wskazana w punktach (i)-(vii) musi być rzeczywiście prowadzona, a tym samym przyczyniać się do realizacji celów Wspólnej Polityki Rolnej określonych w art. 39 TFUE. Warto przypomnieć, że celami Wspólnej Polityki Rolnej są m.in.: zapewnienie odpowiedniego poziomu życia ludności wiejskiej, zwłaszcza przez podniesienie indywidualnego dochodu osób pracujących w rolnictwie; stabilizacja rynków; zagwarantowanie bezpieczeństwa dostaw oraz rozsądnych cen dla konsumentów.

W rozporządzeniu unijnym nr 1308 bardzo ogólnie odniesiono się do statutu organizacji producentów, zwaracjąc uwagę jedynie na kilka kwestii, które muszą być w nim zawarte. Przykładowo konieczne jest postanowienie wskazujące, że od producentów rolnych będących członkami organizacji w szczególności wymaga się: stosowania przyjętych przez nią przepisów dotyczących sprawozdawczości produkcyjnej, produkcji, wprowadzania do obrotu i ochrony środowiska. Niezbędne jest także postanowienie o przynależności z tytułu wytwarzania określonego produktu w danym gospodarstwie tylko do jednej organizacji. Analizowany akt prawny stanowi jednak, że państwa członkowskie mogą wprowadzić odstępstwo od tego warunku w należycie uzasadnionych przypadkach, np. gdy producenci będący członkami mają dwie różne jednostki produkcyjne znajdujące się na innych obszarach geograficznych.

W statucie organizacji producentów przewiduje się ponadto np.: zobowiązanie członków do wpłacania składek potrzebnych do finansowania organizacji producentów; przepisy umożliwiające producentom-członkom demokratyczną kontrolę ich organizacji i jej decyzji. To postanowienie zależy od formy prawnej organizacji. Należy wyraźnie pokreślić, że rozporządzenie unijne nie wskazuje formy prawnej organizacji producentów rolnych. W tym zakresie dodatkowe 
wymogi mogą wynikać z przepisów krajowych. Demokracja występuje w spółdzielniach, w których co do zasady jeden spółdzielca ma jeden głos. W odniesieniu do spółek handlowych i innych podmiotów przepisy o organizacjach przewidują $z$ reguły dodatkowe warunki konieczne do zachowania ustroju demokratycznego.

Istotne są postanowienia w statucie dotyczące zapłaty kary za naruszenie obowiązków określonych w dokumentach organizacji, w szczególności za nieuiszczenie składek lub naruszenie zasad ustalonych przez organizację producentów. Ważne są także zasady przyjmowania nowych członków, zwłaszcza minimalny okres członkostwa, który nie może być krótszy niż rok.

\subsection{Regulacje krajowe}

Problematykę organizacji producentów rolnych poruszono w ustawie z 11 marca 2004 r. o organizacji niektórych rynków rolnych i wydanym na jej podstawie rozporządzeniu wykonawczym. Artykuł 38i tego aktu prawnego określa, że dyrektor oddziału regionalnego Agencji Restrukturyzacji i Modernizacji Rolnictwa właściwy ze względu na siedzibę wnioskodawcy jest organem w sprawach uznawania organizacji producentów, zrzeszeń organizacji producentów oraz organizacji międzybranżowych, w tym międzynarodowych organizacji producentów, międzynarodowych zrzeszeń organizacji producentów oraz międzynarodowych organizacji międzybranżowych.

Rozporządzenie Ministra Rolnictwa i Rozwoju Wsi z 7 stycznia 2016 r. w sprawie uznawania organizacji producentów i zrzeszeń organizacji producentów oraz organizacji międzybranżowych funkcjonujących na rynkach rolnych innych niż rynki mleka i przetworów mlecznych oraz owoców i warzyw zmienione przez par. 1 pkt 1 rozporządzenia z dnia 27 czerwca 2019 r. (Dz.U. 2019, poz. 1293) wskazuje, że organizacja producentów musi liczyć minimum dziesięciu członków będących producentami produktu lub grupy produktów, należących do jednego z sektorów wymienionych rozporządzeniu unijnym nr 1308/2013 (w art. 1 ust. 2 lit. a-h, l-o oraz q-x). Rozporządzenie stanowi także, że członkowie organizacji producentów będący producentami produktu lub grupy produktów stanowią co najmniej $80 \%$ liczby członków tej organizacji. Wniosek o uznanie organizacji producentów, zrzeszenia organizacji producentów albo organizacji międzybranżowej zawiera m.in.: nazwę, siedzibę, adres, wskazanie formy prawnej i numer w Krajowym Rejestrze Sądowym (dalej: KRS) oraz wskazanie produktu lub grupy produktów, ze względu na które podmiot ubiega się o uznanie. Ustawodawca krajowy nie ogranicza formy prawnej organizacji, wspomina tylko o numerze w KRS. 
Organizacja producentów do wniosku dołącza: kopię statutu lub umowy, lub innego aktu założycielskiego organizacji producentów, plan biznesowy (zawierający m.in. zakres i opis działań, jakie zamierza ona zrealizować przez okres co najmniej 5 kolejnych lat, aby osiągnąć cel albo cele, ze względu na które ubiega się o uznanie, wraz ze wskazaniem potrzeby realizacji planowanych działań i określeniem stanu ich wykonania w poszczególnych latach wykonania planu biznesowego oraz uzasadnieniem, w jaki sposób poszczególne działania przyczynią się do osiągnięcia ww. celu albo celów, ze względu na które organizacja producentów ubiega się o uznanie). Postanowienia planów biznesowych, a potem ich realizacja są szczególnie istotne w aspekcie rozwoju gospodarstw rolnych członków.

Warto dodać, że dyrektor oddziału regionalnego ARiMR przeprowadza co najmniej raz na dwa lata kontrole uznanych organizacji i zrzeszeń w zakresie określonym przepisami Unii Europejskiej dotyczącymi uznawania organizacji producentów i zrzeszeń organizacji producentów oraz organizacji międzybranżowych.

\section{Organizacje producentów w sektorze mleka i przetworów mlecznych}

\subsection{Regulacje unijne}

W rozporządzeniu Parlamentu Europejskiego i Rady nr 1308/2013 z 17 grudnia 2013 r. oprócz ogólnych przepisów dotyczących organizacji producentów rolnych, występują także te poświęcone tylko organizacji producentów w sektorze mleka i przetworów mlecznych. Artykuł 161 rozporządzenia unijnego określa, że państwa członkowskie na wniosek uznają za organizacje producentów w sektorze mleka i przetworów mlecznych całe podmioty prawne lub wyraźnie określone ich części pod warunkiem spełnienia poniżej opisanych warunków. Likwidując kwoty mleczne w 2015 r., Unia Europejska wprowadziła instrumenty zabezpieczenia dla producentów rolnych. Jednym z nich było zwiększenie znaczenia organizacji producentów w sektorze mleka i przetworów mlecznych. Mają one negocjować umowy o dostawę mleka do przetwórcy tego surowca i zapewniać, że producenci mleka otrzymają bardziej sprawiedliwe zapłaty, pokrywające rosnące koszty produkcji. Zdaniem Komisji Europejskiej kluczowe znaczenie dla rozwoju gospodarstw rolnych i europejskiego rolnictwa ma współpraca i zrzeszanie się rolników.

Rozporządzenie Parlamentu Europejskiego i Rady nr 1308/2013 wskazuje, że ustanowione przez producentów w sektorze mleka i przetworów mlecznych 
organizacje producentów rolnych powstały z ich inicjatywy oraz dążą do realizacji określonego celu, który może obejmować jeden lub większą liczbę z następujących: (a) zapewnienie planowania i dostosowywania produkcji do popytu, w szczególności w odniesieniu do jakości i ilości; (b) koncentracja podaży oraz wprowadzanie do obrotu produktów wytwarzanych przez ich członków; (c) optymalizacja kosztów produkcji oraz stabilizowanie cen producentów.

Omawiany unijny akt prawny akcentuje także, że organizacje mają minimalną liczbę członków lub wytwarzają określaną przez dane państwo członkowskie minimalną wielkość zbywalnej produkcji w sektorze, w którym działają. Poza tym muszą właściwie prowadzić swoją działalność zarówno w kategoriach czasu, jak i efektywności oraz koncentracji podaży, a także mają statut, który jest zgodny $\mathrm{z}$ art. 161 rozporządzenia unijnego.

Analizowany akt prawny zawiera regulacje prawne dotyczące negocjacji umownych w sektorze mleka i przetworów mlecznych (art. 148 rozporządzenia Parlamentu Europejskiego i Rady nr 1308/2013 z 17 grudnia 2013 r.). Organizacja producentów może mianowicie w imieniu swoich członków będących rolnikami w odniesieniu do części lub całości ich wspólnej produkcji - negocjować umowy o dostawę przez rolnika mleka surowego do przetwórcy mleka surowego lub do nabywcy. Rozporządzenie wskazuje, że negocjacje mogą być prowadzone przez organizację producentów: bez względu na to, czy ma miejsce przeniesienie prawa własności do mleka surowego przez rolników na organizację producentów; czy negocjowana cena jest taka sama w odniesieniu do wspólnej produkcji niektórych lub wszystkich rolników należących do organizacji. Konieczne jest jednak spełnienie kliku warunków, np. ilość mleka surowego objęta takimi negocjacjami nie przekracza: 3,5\% całkowitej produkcji unijnej, 33\% całkowitej produkcji krajowej tego państwa członkowskiego. W rozporządzeniu określono także, że negocjacje umowne są możliwe, gdy mleko surowe nie podlega obowiązkowi dostaw wynikającemu z członkostwa rolnika w spółdzielni zgodnie z warunkami określonymi w statucie spółdzielni lub przepisach i decyzjach w nim zawartych lub z niego wynikających. Należy wyraźnie zaakcentować, że ustawodawca unijny wskazał, że organizacja może, ale nie musi negocjować. Oznacza to, że decyzja o podjęciu takiej aktywności należy do niej.

Według regulacji unijnych negocjacje nie mogą być prowadzone, gdy mleko surowe podlega obowiązkowi dostaw wynikającemu z członkostwa rolnika w spółdzielni zgodnie z warunkami określonymi w statucie spółdzielni lub przepisach i decyzjach w nim zawartych lub z niego wynikających. Nie jest $\mathrm{z}$ reguły zasadne, aby producent rolny rezygnował z członkostwa w spółdzielni mleczarskiej celem udziału w organizacji. Powstaje pytanie, czy spółdzielnie 
mleczarskie, których członkami są producenci rolni, mogą starać się o uznanie za organizację producentów rolnych. Wydaje się, że jeżeli spełniają wymagania wynikające z unijnych i polskich przepisów, jest to możliwe. Organizacja może zajmować się bowiem także wspólnym przetwarzaniem produktów dostarczonych przez członków (art. 151 rozporządzenia unijnego). Jak zostało zaznaczone, ponad 50\% organizacji producentów rolnych w UE ma formę spółdzielni.

\subsection{Regulacje krajowe}

Nie istnieje odrębna polska ustawa regulująca zakładanie i rejestrację organizacji producentów, w tym w sektorze mleka i przetworów mlecznych, jak ma to miejsce w przypadku grup producentów rolnych (ustawa z 15 września $2000 \mathrm{r}$. o grupach producentów rolnych i ich związkach oraz o zmianie innych ustaw, t.j. Dz.U. 2018, poz. 1026 ze zm., dalej: ustawa o grupach producentów rolnych). Podstawy prawne dotyczące organizacji producentów mleka zawarte zostały w ustawie z 20 kwietnia 2004 r. o organizacji rynku mleka i przetworów mlecznych oraz aktach wykonawczych. Organem odpowiedzialnym w sprawach uznawania organizacji i zrzeszeń organizacji producentów mleka, a także organizacji międzybranżowych jest dyrektor oddziału regionalnego ARiMR właściwy ze względu na siedzibę wnioskodawcy. Rejestracja następuje w drodze decyzji na wniosek organizacji albo zrzeszenia (Suchoń, 2016b, s. 297-313).

W omawianej ustawie z 20 kwietnia 2004 r. o organizacji rynku mleka i przetworów mlecznych nie wskazano, że rejestracji w ARiMR podlega podmiot wpisany w KRS. Nie ma także postanowienia, jak w przypadku ustawy o grupach producentów rolnych, że musi to być osoba prawna. Warto odwołać się do par. 2 rozporządzenia Ministra Rolnictwa i Rozwoju Wsi z 5 lutego 2016 r. w sprawie informacji, jakie powinien zawierać wniosek o uznanie organizacji producentów, zrzeszeń organizacji producentów i organizacji międzybranżowych na rynku mleka i przetworów mlecznych oraz rodzaju i zakresu dokumentów potwierdzających spełnienie przez te podmioty warunków uznania (t.j. z 10 stycznia 2019 r.; Dz.U. 2019, poz. 169; dalej: rozporządzenie MRiRW z 5 lutego 2016 r.), zmienionego na podstawie nowelizacji z 31 stycznia 2020 r. (Rozporządzenie Ministra Rolnictwa i Rozwoju Wsi z 31 stycznia 2020 r. zmieniające rozporządzenie w sprawie informacji, jakie powinien zawierać wniosek o uznanie organizacji producentów, zrzeszeń organizacji producentów i organizacji międzybranżowych na rynku mleka i przetworów mlecznych oraz rodzaju i zakresu dokumentów potwierdzających spełnienie przez te podmioty warunków uznania, Dz.U. 2020, poz. 254). Wynika z niego, że podanie o uznanie organizacji producentów, zrzeszenia organizacji 
producentów oraz organizacji międzybranżowej zawiera: nazwę, wskazanie formy prawnej i numer w KRS organizacji producentów, zrzeszenia organizacji producentów albo organizacji międzybranżowej. Do wniosku załączyć należy np. opis struktury organizacji producentów, w tym kwestie udziałów lub liczbę posiadanych akcji i głosów przysługujących poszczególnym członkom, udziałowcom lub akcjonariuszom organizacji producentów na zgromadzeniu wspólników, walnym zgromadzeniu albo walnym zebraniu członków organizacji producentów. Wydaje się, że najlepszymi formami dla organizacji są spółdzielnie ewentualnie spółki z o.o.

Ustawa z 20 kwietnia 2004 r. stanowi, że dyrektor oddziału regionalnego ARiMR uznaje tylko taką organizację producentów, która spełnia łącznie opisane poniżej przesłanki.

Po pierwsze, jest utworzona co najmniej przez 20 członków, a także wytwarza i wprowadza do obrotu rocznie nie mniej niż $2 \mathrm{mln}$ kg mleka lub przetworów mlecznych wyprodukowanych w ramach tej ilości mleka. Należy zwrócić uwagę, że chodzi o mleko nieprzetworzone albo przetwory mleczne. Zaakcentowano zatem, że możliwe jest przetwórstwo. Oznacza to, że producent rolny może dostarczyć mleko nieprzetworzone, przetwory mleczne, czy też organizacja może zajmować się wspólnym przetwórstwem i wprowadzać jego efekty na rynek. Warto podkreślić, że z art. 152 rozporządzenia Parlamentu Europejskiego i Rady nr 1308/2013 z 17 grudnia 2013 r. wynika, że działalnością organizacji może być wspólne przetwarzanie. Przepis ten moim zdaniem ma zastosowanie także do organizacji producentów mleka. Z art. 161 wynikają cele, które są zawarte w ust 1 . Natomiast nie ma przepisu szczególnego do rodzaju działalności. Uzasadnione jest zatem twierdzenie, że nadal ma zastosowania w tym zakresie art. 152 rozporządzenia unijnego. Moim zdaniem liczba 20 producentów rolnych, którzy muszą być zrzeszeni w organizacji, jest zbyt wysoka. Zniechęca to do tworzenia takich podmiotów. Poza tym produkcja mleka jest zróżnicowana w różnych regionach i trudno o zrzeszenie aż 20 producentów mleka.

$\mathrm{W}$ praktyce powstało pytanie, czy obecnie istniejące spółdzielnie, $\mathrm{w}$ tym szczególnie spółdzielnie mleczarskie, mogą starać się o uznanie za organizację producentów mleka. W mojej opinii jest to możliwe, gdyż jak wskazałam, organizacje mogą zajmować się wspólnym przetwarzaniem. Takie postanowienia dają szansę, szczególne mniejszym spółdzielniom mleczarskim, na staranie się o środki unijne, o ile spełnione zostały zasady dotyczące finansowania określone w polskich i unijnych regulacjach prawnych, o czym w dalszej części artykułu.

Według rozporządzenia polskiego we wniosku do ARiMR o uznanie należy wskazać także ilość mleka lub przetworów mlecznych wytwarzanych rocznie i wprowadzanych do obrotu przez organizację producentów albo zrzeszenie 
organizacji producentów. W ustawie z 20 kwietnia 2004 r. nie sprecyzowano, jaką ilość mleka ma wprowadzić każdy producent mleka. Wskazano jedynie na łączny minimalny poziom tego produktu. W ustawie nie zawarto także definicji ani wskazania cech charakterystycznych członka organizacji. Analiza regulacji prawnych pozwala na uznanie, że będzie nim przede wszystkim producent mleka lub przetworów mlecznych spełniający wymagania określone w ustawie.

Po drugie, w okresie 12 miesięcy poprzedzających miesiąc złożenia wniosku co najmniej 20 członków tej organizacji wytwarzało i wprowadzało do obrotu mleko lub przetwory mleczne. Producenci rolni muszą funkcjonować na rynku mleka co najmniej od roku, gdyż mają obowiązek wykazać wprowadzenie do obrotu mleka albo przetworów tego produktu. Organizacja może liczyć więcej członków, w tym także osoby, które w ostatnim roku nie wprowadzały mleka czy przetworów mlecznych na rynek. Dla rejestracji podmiotu istotnych jest 20 osób, które spełniają wymagania wskazane w przepisach.

Po trzecie, cała ilość mleka lub przetworów mlecznych wyprodukowana w gospodarstwach członków tej organizacji jest wprowadzana do obrotu za jej pośrednictwem. Regulacja ta uniemożliwia sprzedaż mleka albo produktów mleczarskich bezpośrednio przedsiębiorcom czy konsumentom. Natomiast część mleka można wykorzystywać na potrzeby własne. W ustawie wskazano, że chodzi o wprowadzanie do obrotu za pośrednictwem organizacji.

Po czwarte, okres wypowiedzenia członkostwa w tej organizacji jest nie krótszy niż sześć miesięcy i spełnia wymagania określone w art. 161 ust. 1 lit. a i d rozporządzenia unijnego nr 1308. Wydaje się on być zbyt krótki. Co więcej, nie zostały uwzględnione powody wypowiedzenia, np. przekazanie gospodarstwa rolnego następcy.

W ustawie z 20 kwietnia 2004 r. o organizacji rynku mleka uregulowano także zagadnienie zrzeszenia organizacji producentów, wskazując warunki, które musi spełniać taki podmiot. Mianowicie ma on być utworzony przez co najmniej dwie uznane organizacje producentów; w jego statucie musi zostać określona minimalna ilość mleka lub przetworów mlecznych wyprodukowanych w gospodarstwach członków organizacji tworzących to zrzeszenie, a mleko być wprowadzane do obrotu przez organizacje za pośrednictwem zrzeszenia.

Rejestry organizacji producentów rolnych i ich zrzeszeń prowadzi w postaci elektronicznej dyrektor oddziału regionalnego ARiMR. Są on jawne i udostępniane na stronie internetowej. Rola dyrektora oddziału regionalnego ARiMR nie kończy się jednak z chwilą rejestracji takiej organizacji. 


\section{Finansowanie organizacji producentów rolnych}

Na szczególną uwagę zasługują ostatnie zmiany zasad finansowania ze środków unijnych. Z dniem 20 maja 2020 r. weszło w życie rozporządzenie (Rozporządzenie Ministra Rolnictwa i Rozwoju Wsi z 27 kwietnia 2020 r. zmieniające rozporządzenie w sprawie szczegółowych warunków i trybu przyznawania, wypłaty oraz zwrotu pomocy finansowej w ramach działania „Tworzenie grup producentów i organizacji producentów” objętego Programem Rozwoju Obszarów Wiejskich na lata 2014-2020, Dz.U. 2020, poz. 799) zmieniające rozporządzenie z 2 sierpnia 2016 r. w sprawie szczegółowych warunków i trybu przyznawania, wypłaty oraz zwrotu pomocy finansowej w ramach działania „Tworzenie grup producentów i organizacji producentów” objętego Programem Rozwoju Obszarów Wiejskich na lata 2014-2020. Modyfikacja wprowadziła możliwość starania się o dofinansowanie przez organizacje producentów rolnych. Obecnie o pomoc może ubiegać się po pierwsze, grupa producentów rolnych, która została utworzona ze względu na produkt lub grupę produktów inne niż drób żywy (bez względu na wiek), mięso lub jadalne podroby drobiowe: świeże, chłodzone, mrożone, o których mowa w rozporządzeniu Ministra Rolnictwa i Rozwoju Wsi z 19 kwietnia 2016 r. w sprawie wykazu produktów i grup produktów, ze względu na które mogą być tworzone grupy producentów rolnych, minimalnej rocznej wielkości produkcji towarowej oraz minimalnej liczby członków grupy producentów rolnych; po drugie, organizacja producentów uznana nie wcześniej niż 1 stycznia 2014 r. na podstawie przepisów ustawy z 11 marca 2004 r. o organizacji niektórych rynków rolnych albo 20 kwietnia 2004 r. o organizacji rynku mleka i przetworów mlecznych. Co więcej, została utworzona ze względu na produkt lub grupę produktów innych niż należące do sektora mięsa drobiowego, o których mowa w części XX załącznika I do rozporządzenia Parlamentu Europejskiego i Rady (UE) nr 1308/2013 z dnia 17 grudnia 2013 r. ustanawiającego wspólną organizację rynków produktów rolnych.

Warto także nawiązać do art. 27 rozporządzenia Parlamentu Europejskiego i Rady nr 1305/2013 w którym określono, że wsparcia w ramach tworzenia grup i organizacji producentów udziela się, aby ułatwić ich tworzenie i organizacji producentów w sektorach rolnictwa i leśnictwa do celów: a) dostosowania do wymogów rynkowych procesu produkcyjnego i produktów producentów, którzy są członkami takich grup lub organizacji; b) wspólnego wprowadzania towarów do obrotu, w tym przygotowania do sprzedaży, jej centralizacji i dostawy do odbiorców hurtowych; c) ustanowienia wspólnych zasad dotyczących informacji o produkcji ze szczególnym uwzględnieniem zbiorów i dostępności oraz d) innych zadań, które mogą być prowadzone przez grupy i organizacje 
producentów, takich jak rozwijanie umiejętności biznesowych i marketingowych oraz organizowanie i ułatwianie procesów wprowadzania innowacji. Zakres działania organizacji został określony w rozporządzeniu unijnym nr 1307/2013 dużo szerzej niż cele związane z finansowaniem w rozporządzeniu nr 1305/2013. Uzasadnione zatem wydaje się twierdzenie, że organizacja może określić szerzej przedmiot działalności, ale pomoc finansową może otrzymać, gdy realizuje cele zgodne z tym ostatnim aktem prawnym.

Pomoc jest przyznawana grupie albo organizacji, która np. zobowiąże się do realizacji planu biznesowego; działa jako przedsiębiorca prowadzący mikro-, małe lub średnie przedsiębiorstwo; w jej skład nie wchodzą członkowie będący producentami jednego produktu lub grupy produktów, którzy byli już członkami grupy producentów rolnych, wstępnie uznanej grupy producentów owoców i warzyw lub organizacji producentów owoców i warzyw, utworzonej ze względu na ten sam produkt lub produkt tożsamy z produktem wytwarzanym.

W rozporządzeniu przewidziano także wymagania dotyczące członków, co stanowi nowość w porównaniu z poprzednimi latami finansowania. Każdemu z członków tej grupy czy organizacji będącemu producentem przyznano finansowanie na podstawie przepisów o płatnościach w ramach systemów wsparcia bezpośredniego w roku uznania grupy lub przynajmniej raz w ciągu ostatnich dwóch lat poprzedzających rok uznania grupy. Warunki nie dotyczą osób, które przejęły w całości gospodarstwo rolne w roku poprzedzającym rok uznania grupy albo organizacji lub w roku uznania grupy albo organizacji. Udzielanie pomocy nie ma charakteru ciągłego. Prezes ARiMR podaje do publicznej wiadomości na stronie internetowej ogłoszenie o naborze wniosków o przyznanie pomocy. W 2020 r. odbywał się on w dniach od 19 czerwca 2020 r. do 17 sierpnia 2020 r.

Wniosek o przyznanie pomocy składa się do dyrektora oddziału regionalnego ARiMR właściwego ze względu na siedzibę grupy albo organizacji. Przysługuje ona grupie oraz organizacji według kolejności ustalonej przez Prezesa ARiMR przy zastosowaniu kryteriów wyboru, np. jeżeli grupa albo organizacja jest zorganizowana w formie spółdzielni przyznaje się trzy punkty. Rozporządzenie stanowi także, że jeżeli w planie biznesowym są przewidziane inwestycje przyczyniające się do realizacji celów przekrojowych programu: a) innowacyjności - przez wprowadzenie nowych zasad produkcji, procesu lub technologii, odmiennych od obecnie stosowanych, lub zmianę obecnie stosowanych technologii lub b) przeciwdziałania zmianom klimatu lub ochrony środowiska - przez stosowanie maszyn, urządzeń, sprzętu lub technologii, ograniczających niekorzystne oddziaływanie na środowisko naturalne, lub rozwiązań ograniczających zużycie zasobów, w szczególności wody lub energii, przyznaje się pięć punktów. Wyso- 
kość pomocy w danym roku prowadzenia działalności przez organizację ustala się na podstawie wartości udokumentowanych rocznych przychodów netto ze sprzedaży produktów lub grupy produktów, ze względu na które organizacja została uznana. Dodatkowo ze sprzedaży produktów przetworzonych objętych załącznikiem I do TFUE, wytworzonych z produktów lub grupy produktów, ze względu na które beneficjent został uznany, jeżeli w skład organizacji producentów wchodzi co najmniej 15 członków - przyznaje się cztery punkty, a za każdego kolejnego członka 0,2 punktu (ARiMR, 1).

\section{Organizacje producentów rolnych, a grupy producentów rolnych}

Omawiając prawne zagadnienia organizacji producentów rolnych, warto choć krótko nawiązać do grup producentów rolnych. W tym kontekście zasadne wydaje się wskazanie podstawowych różnic i podobieństw pomiędzy zrzeszaniem się producentów rolnych w ramach organizacji w porównaniu z grupą. Te ostatnie funkcjonują w Polsce od wielu lat, a zasady ich tworzenia i funkcjonowania są znane producentom rolnym. Obecnie działa ponad 900 takich podmiotów (ARiMR, 2), w tym ok. 500 w formie spółdzielni. Podobnie jak w przypadku organizacji są one zakładane przez producentów rolnych i wspierają ich w prowadzonej działalności rolniczej oraz oddziaływaniu na rynek rolny.

Przedmiot działalności organizacji producentów rolnych określony został szerzej w przepisach unijnych dotyczących rynków rolnych niż grup producentów rolnych, choć zakresy są podobne - wpisują się w potrzeby rozwoju gospodarstw rolnych i rynków rolnych. Działalność organizacji skupia się nie tylko na umieszczaniu na rynku produktów wytwarzanych przez ich członków, w tym sprzedaży bezpośredniej, optymalizacji kosztów produkcji, innowacyjnych praktykach, konkurencyjności gospodarczej i rozwoju sytuacji rynkowej, lecz także na wspólnym przetwarzaniu produktów czy opracowywaniu inicjatyw w dziedzinie promocji i wprowadzania do obrotu.

Należy podkreślić, że takie same regulacje dotyczące finansowania, zawarte w rozporządzeniu Parlamentu Europejskiego i Rady (UE) nr 1305/2013 z 17 grudnia 2013 r. w sprawie wsparcia rozwoju obszarów wiejskich przez Europejski Fundusz Rolny na rzecz Rozwoju Obszarów Wiejskich (EFRROW) i uchylające rozporządzenie Rady (WE) nr 1698/2005 (Dz. Urz. UE L z 2013 r., Nr 347, s. 487 ze zm.), są skierowane zarówno dla organizacji, jak i grup producentów rolnych. W preambule ww. dokumentu zaznaczono, że grupy i organizacje producentów 
pomagają rolnikom wspólnie stawiać czoła wyzwaniom związanym z rosnącą konkurencją i konsolidacją rynków niższego szczebla w odniesieniu do wprowadzania ich produktów do obrotu, w tym na rynkach lokalnych. Z tego względu należy zachęcać do tworzenia grup i organizacji producentów.

Grupy są tworzone według ustawy z 15 września 2000 r. o grupach producentów rolnych i ich związkach oraz o zmianie innych ustaw. Jak już wspomniano, w przypadku organizacji producentów rolnych nie ma odrębnego polskiego aktu prawnego. Regulacje zawarte są w dwóch ustawach i rozporządzeniach wykonawczych. Mają one jednak bardziej ogólny charakter. W odniesieniu do organizacji większe znaczenie ma rozporządzenie unijne nr 1308/2013. Nie ulega wątpliwości, że łatwiej założyć grupę niż organizację producentów rolnych. W pierwszym przypadku wystarczy bowiem tylko pięciu producentów rolnych, w tym producentów mleka. Dużo niższa jest także wysokość rocznych dostaw wymagana od członków. W przypadku mleka krowiego to 100 tys. litrów, zbóż 200, 400 lub 600 ton w zależności od województwa. Założenie organizacji wymaga 10 albo 20 członków, a w przypadku rynku mleka podmiot (jej członkowie) wytwarza i wprowadza do obrotu rocznie nie mniej niż 2 mln kilogramów mleka lub przetworów mlecznych wyprodukowanych w ramach tej ilości mleka.

Grupy producentów rolnych od lat mogą korzystać nie tylko ze środków unijnych, lecz także z preferencji podatkowych (które aktualnie nie są przeznaczone dla organizacji producentów rolnych). Przykładowo według art. 7 pkt 13 ustawy z 12 stycznia 1991 r. o podatkach i opłatach lokalnych (Dz.U. 2019, poz. 1170 ze zm.) zwolnione są od podatku od nieruchomości budynki i budowle zajęte przez grupę producentów rolnych wpisaną do rejestru tych grup, wykorzystywane wyłącznie na prowadzenie działalności w zakresie sprzedaży produktów lub grup produktów wytworzonych w gospodarstwach członków grupy lub w zakresie określonym w art. 4 ust. 2 ustawy z dnia 15 września 2000 r. o grupach producentów rolnych zgodnie z jej aktem założycielskim.

\section{Podsumowanie}

Przeprowadzone rozważania w nawiązaniu do celu pracy pozwalają na wysunięcie następujących wniosków.

Po pierwsze, ustawodawca unijny uznaje organizacje producentów rolnych za jeden z podstawowych instrumentów rynkowych Wspólnej Polityki Rolnej. Wpisują się one w obecne wyzwania dotyczące gospodarstw i rynków rolnych, np. przyczyniają się do zapewnienia bezpieczeństwa żywności i żywnościowego, 
poprawiają zdolności produkcyjne rolnictwa unijnego i jego konkurencyjność, zwiększają dochody rolników; kontynuują działania mające na celu łagodzenie skutków zmiany klimatu; wspierają zatrudnienie na terenach wiejskich (zob. szerzej np. Komisja Europejska, 2013). Regulacje prawne dotyczące omawianych podmiotów zawarte są w rozporządzeniach unijnych i krajowych przepisach. Te pierwsze zachęcają producentów rolnych do współpracy i budowania stabilnej struktury organizacyjnej. Przede wszystkim wspomnieć należy o regulacjach dotyczących rynków rolnych, szczególnie mleka oraz owoców i warzyw. Z uwagi choćby na rozbudowaną strukturę oraz przedmiot działalności wpisują się w unijne zasady wielofunkcyjności rolnictwa i zrównoważonego rozwoju obszarów wiejskich. Ta ostatnia przewiduje wspieranie na tych terenach zróżnicowanej działalności gospodarczej, tworzenie nowych miejsc pracy, poprawę warunków życia oraz zapewnienie obywatelom dostępu do szerokiego katalogu usług i nowoczesnej infrastruktury. Organizacje wpisują się nie tylko we Wspólną Politykę Rolną, lecz także w realizację polityki regionalnej (zob. Kokocińska, 2010, s. 14 i nn.; Pastuszka, 2012, s. 11 i nn.) Unii Europejskiej, która skupia się na zwiększaniu spójności ekonomicznej i społecznej. Jak podkreśla się w literaturze - europejska polityka regionalna zmierza do harmonijnego rozwoju Unii Europejskiej, niwelowania różnic, czyli osiągania spójności pomiędzy różnymi obszarami pod względem rozwoju społeczno-gospodarczego (Grosse, 2000, s. 7 i nn.).

Po drugie, jak dotąd organizacje producentów rolnych w Polsce nie cieszą się popularnością. Czynnikiem stanowiącym barierę może być wysoka liczba producentów rolnych (aż 20 na rynku mleka), jak i dostarczanych produktów rolnych (np. 2 mln kilogramów mleka lub przetworów mlecznych). Co więcej, dopiero w maju 2020 r. weszły w życie zmienione polskie regulacje prawne obejmujące organizacje jako podmioty, które obok grup producentów rolnych mogą starać się o środki unijne z programu „Tworzenie grup producentów i organizacji producentów" objętego Programem Rozwoju Obszarów Wiejskich na lata 20142020. Jak dotąd mogły z niego korzystać tylko grupy. Czynnik finansowy może przyczynić się do rozważania przez producentów rolnych powołania organizacji, choć trudno przesądzić, czy będzie on wystarczający. Prawodawca polski stara się zachęcać producentów rolnych do rejestrowania organizacji producentów rolnych, zmieniając także inne regulacje prawne. Jak wspomniano, w latach 2019-2020 znowelizowano rozporządzenia wykonawcze do ustawy z 20 kwietnia $2004 \mathrm{r}$. o organizacji rynku mleka i przetworów mlecznych (Rozporząazenie Ministra Rolnictwa i Rozwoju Wsi z 31 stycznia 2020 r. zmieniające rozporządzenie $\mathrm{w}$ sprawie informacji, jakie powinien zawierać wniosek o uznanie organizacji producentów, zrzeszeń organizacji producentów i organizacji międzybranżowych 
na rynku mleka i przetworów mlecznych oraz rodzaju i zakresu dokumentów potwierdzających spełnienie przez te podmioty warunków uznania) oraz ustawy z 11 marca 2004 r. o organizacji niektórych rynków rolnych (Rozporządzenie z 7 stycznia 2016 r. w sprawie uznawania organizacji producentów i zrzeszeń organizacji producentów oraz organizacji międzybranżowych funkcjonujących na rynkach rolnych innych niż rynki mleka i przetworów mlecznych oraz owoców i warzyw zmienione przez rozporządzenie Ministra Rolnictwa i Rozwoju Wsi z 27 czerwca 2019 r. zmieniające rozporządzenie w sprawie uznawania organizacji producentów i zrzeszeń organizacji producentów oraz organizacji międzybranżowych funkcjonujących na rynkach rolnych innych niż rynki mleka i przetworów mlecznych oraz owoców i warzyw) dotyczące wybranych kwestii zakładania organizacji producentów rolnych, w tym mleka. Nadal jednak organizacje producentów rolnych nie mogą korzystać z preferencji podatkowych przeznaczonych dla grup producentów rolnych (przede wszystkim podatku od nieruchomości oraz podatku dochodowego od osób prawnych). W przypadku rynku mleka w Polsce spółdzielnie mleczarskie znacząco wpływają na jego funkcjonowanie, co należy ocenić pozytywnie.

Po trzecie, w perspektywie Wspólnej Polityki Rolnej po 2021 r. istotne jest, aby polscy producenci rolni występowali o rejestrację organizacji producentów rolnych. W tym kontekście zasadne wydaje się stworzenie zbliżonych uwarunkowań prawnych dla organizacji jak dla grup producentów rolnych. W obecnej sytuacji, mimo zmiany regulacji dotyczących finansowania, nadal mogą one nie cieszyć się zbytnim zainteresowaniem rolników. Warto, aby prawodawca rozważył uchwalenie odrębnej ustawy o organizacjach producentów rolnych, podobnie jak w przypadku ustawy o grupach producentów rolnych. Regulacje prawne dotyczące organizacji można podzielić na te przed rejestracją, po dokonaniu uznania i związane z jej funkcjonowaniem oraz te dotyczące kontroli i ewentualnego zakończenia działalności. W przypadku pierwszych dość duże znaczenie mają regulacje unijne. To właśnie te przepisy wskazują zakres ich działania i niektóre postanowienia statutu. Biorąc pod uwagę technikę legislacyjną, powinno nastąpić odwołanie do unijnych regulacji prawnych bez ich powtarzania. Uzasadnione wydaje się objęcie ustawą wszystkich organizacji producentów rolnych działających na każdym z rynków, tj. mleka, owoców i warzyw oraz pozostałych. Z uwagi na regulacje unijne nastąpi zróżnicowanie w zależności od rynków. Nie powinno to jednak stanowić problemu. Rozporządzenie unijne nr 1308/2013 przewiduje także niejednolite rozwiązania prawne w odniesieniu do organizacji producentów rolnych z uwagi na wytwarzane produkty rolne. W nowej ustawie mógłby znaleźć się także przepis określający 
(podobnie jak w przypadku grup producentów rolnych), że spółdzielnia może również prowadzić działalność jako organizacja producentów rolnych, jeżeli m.in. wszyscy wchodzący w jej skład producenci jednego produktu lub grupy produktów spełniają wymagania określone w przepisach polskich i unijnych, a sama spółdzielnia prowadzi działalność na podstawie statutu spełniającego zasady wskazane także w regulacjach prawnych unijnych i polskich. W zakresie rejestracji instytucją właściwą dla wszystkich organizacji byłby ARiMR, a ustawa wymieniałaby dokumenty, które podmiot starający się o uznanie jest zobowiązany dostarczyć, oraz określałaby procedurę z tym związaną. W dalszej części akt prawny zawierałby regulacje prawne dotyczące kontroli i nadzoru ARiMR.

Zasadna wydaje się także zmiana Kodeksu cywilnego w art. 613 w przepisach poświęconych kontraktacji. W obecnym $₫ 4$ wskazano, że przez producenta rolnego rozumie się również grupę producentów rolnych lub ich związek oraz spółdzielnię rolników w rozumieniu ustawy z 4 października 2018 r. o spółdzielniach rolników lub ich związek. W powyższym kontekście logiczne wydaje się uznanie za producenta rolnego także organizacji producentów rolnych. Warto rozważyć wprowadzenie zwolnienia od podatku od nieruchomości w ustawie o podatkach i opłatach lokalnych również dla organizacji producentów rolnych. Chodzi o preferencje skierowane obecnie tylko do grup producentów rolnych. Na marginesie warto zaznaczyć, że objęcie zwolnieniem uznanych organizacji producentów owoców i warzyw wydaje się raczej mało prawdopodobne, gdyż dyskusja w tym zakresie podnoszona jest od kilku lat (zob. Suchoń, 2013, s. 11-32).

Skoro dla rozwoju polskiego rolnictwa bardziej korzystne są organizacje producentów rolnych, to polski prawodawca powinien stworzyć uwarunkowania prawne równe dla grup i organizacji producentów rolnych. W przeciwnym razie grupy mogą nadal cieszyć się większą popularnością niż organizacje. Dobrym rozwiązaniem byłoby występowanie o uznanie za organizację producentów rolnych przez spółdzielnie rolników. Podmioty te działające na podstawie ustawy z 4 października 2018 r. korzystają także ze zwolnień w podatkach i innych preferencji. W takiej oczywiście sytuacji spółdzielnia rolników czy inna funkcjonująca spółdzielnia (np. spółdzielnia mleczarska) musi spełnić wymagania niezbędne dla uznania jej za organizację producentów rolnych.

Reasumując, można wysunąć główny wniosek (tezę), że organizacje producentów rolnych uznać należy za jeden z podstawowych instrumentów rynkowych Wspólnej Polityki Rolnej, jednak ich popularność w państwach Unii Europejskiej jest zróżnicowana. W Polsce jak dotąd nie cieszą się popularnością. Krajowy ustawodawca stara się wprowadzać regulacje prawne zachęcające producentów rolnych do zrzeszania i rejestracji organizacji. Niezbędne są jednak dalsze zmia- 
ny przepisów prawnych. Obecnie bardziej sprzyjające uwarunkowania prawne występują w odniesieniu do zakładania i funkcjonowania grup producentów rolnych niż organizacji.

\section{Bibliografia}

\section{Literatura}

Bijman, J. (2016). The changing nature of farmer collective action: introduction to the book. W: J. Bijman, J. Schuurman, R. Muradian (Eds.), Cooperatives, Economic Democratization and Rural Development. Cheltenham: Edward Elgar Publishing.

Bijman, J., Schuurman J., Muradian R. (Eds.) (2016). Cooperatives, Economic Democratization and Rural Development. Cheltenham: Edward Elgar Publishing.

Busse, C. (2013). Nowa niemiecka ustawa o strukturze rynku rolnego z 2013 r. - rolnicze organizacje producentów i związki branżowe w prawie niemieckim. Przegląd Prawa Rolnego, 1(12), 173-187.

Busse, C. (2020). Quo vadis Agrarorganisationenrecht? - Eine kurze Betrachtung in sechs Kapiteln. W: A. Suchoń (red.), Legal and economic aspect of associations of agricultural producers in the selected countries of the world (s. 106-120). Poznań: Wyd. UAM.

Canfora, I. (2018). Organizzazione dei produttori agricoli, "Digesto discipline Privatistiche, XI aggiornamento UTET", 355-370.

Del Con,t C., Macé, A. (2020). Les organisations de producteurs en France: état des lieux et réflexions. W: A. Suchoń (red.), Legal and economic aspect of associations of agricultural producers in the selected countries of the world (s. 61-80). Poznań: Wyd. UAM.

Giel, T., Bijman, J., Oorthuizen, J. (Eds.). (2007). Producer organisations and market chains: Facilitating Trajectories of Change in Developing Countries. Wageningen: Wageningen Academic Publishers.

Grosse, T.G. (2000). Polityka regionalna Unii Europejskiej i jej wplyw na rozwój gospodarczy. Przykład Grecji, Wloch, Irlandii i wnioski dla Polski. Warszawa: Instytut Spraw Publicznych.

Kokocińska, K. (2010). Polityka regionalna w Polsce i w Unii Europejskiej. Poznań: Wyd. UAM.

Le Clerc, L., Bouamra-Mechemache, Z., Duvaleix-Treguer, S., Magdelaine P., Roguet C., You G. (2019). Rôles des organisations de producteurs dans les filières animales: négociation, conseil, commercialisation et création de valeur. Notes et études socio-économiques, 60-79. 
Mwambi, M., Bijman, J., Mshenga, P. (2020). Which type of producer organization is (more) inclusive? Dynamics of farmers' membership and participation in the decision-making process. Annals of Public and Cooperative Economics, 91(2), 213-226. doi: 10.1111/apce.12269

Pastuszka, S. (2012). Polityka regionalna Unii Europejskiej. Cele, narzędzia, efekty. Warszawa: Difin.

Petriccione, G., Solazzo R. (2012). Le Organizzazioni dei produttori nell'agricoltura Italiano. Agriregionieuropa, 8(30), 18-25.

Suchoń, A. (2013). Prawne aspekty zakładania i prowadzenia działalności przez wstępnie uznane grupy oraz organizacje producentów owoców i warzyw. Przegląd Prawa Rolnego, 2, 11-32.

Suchoń, A. (2015). Grupy i organizacje producentów rolnych wobec wyzwań Wspólnej Polityki Rolnej 2014-2020. Studia Iuridica Agraria, 13, 133-150.

Suchoń, A. (2016a). Prawna koncepcja spółdzielni rolniczych. Poznań: Wyd. UAM.

Suchoń, A. (2016b). Funkcjonowanie rynku mleka po likwidacji kwotowania - wybrane aspekty prawne. Studia Iuridica Agraria, 14, 297-313.

Zoeteweij-Turhan, M. (2012). The Role of Producer Organizations on the Dairy Market. Baden-Baden: Nomos.

\section{Źródła online}

ARiMR (a).Działanie 9 Tworzenie grup producentów i organizacji producentów. Pobrano z: https://www.arimr.gov.pl/pomoc-unijna/prow-2014-2020/dzialanie-9-tworzenie-grup-producentow-i-organizacji-producentow-dzialanie-9-prow-2014-2020. html (08.07.2020).

ARiMR (b). Rejestr grup producentów rolnych. Pobrano z: https://www.arimr.gov.pl/ grupy-i-organizacje-producentow/rejestry-prowadzone-przez-arimr/rejestr-grup-producentow-rolnych.html (08.07.2020).

FAO. (2010). Producer organisations: Reclaiming opportunities for development. Pobrano z: http://www.fao.org/3/am072e/am072e00.pdf (05.07.2020).

Van Herck, K. (2014). Assessing efficiencies generated by agricultural producer organisations. Pobrano z: https://op.europa.eu/en/publication-detail/-/publication/97e19ef2-ddb4-43d7-8392-2fc908fab786/language-en (07.07.2020).

Komisja Europejska. (2019). Study of the best ways for producer organisations to be formed, carry out their activities and be supported. Pobrano z: http://real.mtak. hu/105490/1/report-producer-organisations-study_en.pdf (29.07.2020).

Komisja Europejska. (2020). Komunikat Komisji do Parlamentu Europejskiego, Rady, Europejskiego Komitetu Ekonomiczno-Społecznego i Komitetu Regionów, strategia „od pola do stołu” na rzecz sprawiedliwego, zdrowego i przyjaznego dla środow- 
iska systemu żywnościowego. Pobrano z: https://eur-lex.europa.eu/resource. html?uri=cellar:ea0f9f73-9ab2-11ea-9d2d-01aa75ed71a1.0015.02/DOC_1\&format $=$ PDF (24.05.2020).

Ministère de l'Agriculture et de l'Alimentation. (2020). Organisation économique: les organisations de producteurs. Pobrano z: https://agriculture.gouv.fr/organisation-economique-les-organisations-de-producteurs (24.05.2020).

Rondot, P., Collion, M-H. (Eds.). (2001). Agricultural Producer Organizations Their Contribution to Rural Capacity Building and Poverty Reduction. Pobrano z: http:// documents.worldbank.org/curated/en/111471468740104722/pdf/multi0page. $\operatorname{pdf}(20.04 .2020)$.

\section{Streszczenie}

Celem rozważań była próba określenia kształtu prawnego zakładania, uznawania i funkcjonowania organizacji producentów rolnych (ze szczególnym uwzględnieniem zmian regulacji prawnych z 2019 i 2020 r.) oraz ich oceny w kontekście obecnych wyzwań dotyczących gospodarstw i rynków rolnych. Starano się także ustalić, które regulacje prawne stanowią barierę w zakresie zakładania i rozwoju organizacji producentów rolnych oraz wskazać propozycje ich zmiany. Rozważania skoncentrowano przede wszystkim na regulacjach unijnych dotyczących organizacji producentów rolnych (w tym zwłaszcza na rozporządzeniu Parlamentu Europejskiego i Rady (UE) nr 1308/2013 z 17 grudnia 2013 r. ustanawiających wspólną organizację rynków produktów rolnych) oraz znowelizowanych w 2019 i 2020 r. polskich przepisach. Poruszono zagadnienie europejskiego Zielonego Ładu i strategii na rzecz bioróżnorodności 2030 oraz „od pola do stołu” opublikowanych w maju 2020 r. przez Komisję Europejską. Do realizacji założeń wynikających z tych unijnych dokumentów mogą przyczynić się właśnie organizacje producentów rolnych, są one również ważne w aspekcie rozwoju gospodarstw i rynków rolnych. W dalszej części rozważań wskazano różnice i podobieństwa pomiędzy organizacjami a grupami producentów rolnych. W konkluzji stwierdzono m.in., że czynnikiem stanowiącym barierę w zakresie uznawania organizacji jest prawdopodobnie m.in. wysoka liczba producentów rolnych konieczna do rejestracji, jak i ilość dostarczanych produktów rolnych. Pozytywnie oceniono zmiany regulacji prawnych, które weszły w życie w maju 2020 r. Pozwalają one na korzystanie także przez organizacje producentów rolnych ze środków unijnych z działania „Tworzenie grup producentów i organizacji producentów” objętego Programem Rozwoju Obszarów Wiejskich na lata 2014-2020. Na koniec zaproponowano uchwalenie odrębnej ustawy o organizacjach producentów rolnych, regulującej zasady zakładania i funkcjonowania omawianych podmiotów.

SŁOWA KLUCzowE: organizacje producentów rolnych, rynki rolne, spółdzielnie, Wspólna Polityka Rolna, rynek mleka. 


\section{Summary}

The article aims, firstly, to define the legal framework of the way agricultural producer groups are established, recognized and how they operate (with particular attention given to amendments to legal regulations of 2019 and 2020) and to assess them in the context of current challenges that farms and agricultural markets are facing, and secondly, determining which legal regulations constitute a barrier to the establishment and development of agricultural producer organizations and indication of proposals fortheir amendment. The considerations focusprimarily on EU regulations on agricultural producer organisations (including, in particular, Regulation (EU) No 1308/2013 of the European Parliament and of the Council of 17 December 2013 establishing a common organisation of the markets in agricultural products and repealing Council Regulations (EEC) No 922/72, (EEC) No 234/79, (EC) No 1037/2001 and (EC) No 1234/2007) and the Polish regulations amended in 2019 and 2020. The issue of the European Green Deal and the 2030 biodiversity strategy and "farm to fork" published in May 2020 by the European Commission is discussed. It is agricultural producer organisations that can contribute to the implementation of the assumptions included in those EU documents and they are important in terms of the development of farms and agricultural markets. Further on, the publication points out to the differences and similarities between organisations and groups of agricultural producers. In the conclusion, the author states, inter alia, that the factors hindering the recognition of the organisations include a high number of agricultural producers necessary for registration and the amount of supplied agricultural products. She positively assesses the amendments to the legal regulations that entered into force in May 2020. They allow agricultural producer organisations to use EU funds under the measure "Creation of producer groups and producer organisations" covered by the Rural Development Program for 2014-2020. Finally, she proposes adopting a separate act on agricultural producer organisations, regulating the principles of establishing and functioning of the entities in questions.

KEYWORDS: agricultural producer organisations, agricultural markets, cooperatives, Common Agricultural Policy, milk market.

\section{Nota o autorze}

Aneta Suchoń - dr hab., prof. UAM, Zakład Prawa Rolnego, Żywnościowego i Ochrony Środowiska, Wydział Prawa i Administracji UAM, Poznań; główne obszary działalności naukowej: prawo rolne, gospodarka nieruchomościami, prawo spółdzielcze, prawo ochrony środowiska, prawo żywnościowe; e-mail: suchon@amu.edu.pl; ORCID: 0000-0002-5410-7853. 